\title{
„Zdecydowanie żydowskie, wyraźnie polskie”... Strategie narracyjne twórców Muzeum Historii Żydów Polskich Polin
}

\section{KEYWORDS}

discursive narratives, Jewish identity, Polin Museum of the History of Polish Jews

\begin{abstract}
Cukras-Stelągowska Joanna, „Zdecydowanie żydowskie, wyraźnie polskie"... Strategie narracyjne twórców Muzeum Historii Żydów Polskich Polin [“Definitely Jewish, explicitly Polish..." Narrative strategies of the founders of the Polin Museum of the History of Polish Jews]. Kultura - Społeczeństwo - Edukacja nr 2(12) 2017, Poznań 2017, pp. 379-400, Adam Mickiewicz University Press. ISSN 2300-0422. DOI 10.14746/ kse.2017.12.19.
\end{abstract}

This paper aims to establish a framework of discursive narratives about the idea of the Polin Museum of the History of Polish Jews. Most of these narrative strategies concern the implementation of this huge project, arrangement of exhibitions, topics presented and the importance of the museum for the community of Polish Jews and Poles.

The qualitative analysis of the narratives is conducted based on the content of periodicals published by the Jewish community in Poland: "Midrasz. Pismo Żydowskie" and "Chidusz. Magazyn Żydowski". The analysis involves 11 speeches given immediately after the ceremonial opening of the Museum in 2013 and later, primarily at anniversary celebrations.

Za sprawą mediów w 2014 roku cała Polska szeroko komentowała uroczyste otwarcie Muzeum Historii Żydów Polskich Polin i z zapartym tchem obserwowała pierwsze chwile funkcjonowania jedynego w naszej ojczyźnie muzeum poświęconego w całości Żydom. Niniejszy tekst stanowi próbę ustalenia ram narracji dyskursywnych, które zrodziły się wokół idei muzeum. W szczególności będą to strategie narracyjne dotyczące realizacji tego ogromnego projektu, tematyki wystawy 
stałej i roli, jaką placówka ma odegrać dla społeczności polskich Żydów i Polaków oraz zwiedzających z zagranicy. Strategie te mieszczą się, moim zdaniem, w szerszym kontekście żydowskich dylematów tożsamościowych i stanowią centralną oś współczesnych rozważań społecznych, jak również naukowych z dziedziny tzw. „studiów żydowskich".

\section{„Muzeum Życia"}

Otwarcie muzeum Polin było poprzedzone długoletnimi staraniami i przygotowaniami. Idea zbudowania muzeum poświęconego Żydom polskim narodziła się już w 1995 roku w Stowarzyszeniu Żydowski Instytut Historyczny. Dopiero jednak 19 kwietnia 2013 roku miało miejsce uroczyste otwarcie. Okazały budynek powstał przy ul. Mordechaja Anielewicza, w pobliżu pomnika Bohaterów Getta, w centrum dawnej dzielnicy zamieszkanej przez Żydów (w czasie wojny przekształconej przez Niemców w getto). Wielkie otwarcie wystawy stałej Muzeum Historii Żydów Polskich Polin nastąpiło 28 października 2014 roku. W uroczystości wzięli udział prezydent Bronisław Komorowski i premier Ewa Kopacz, prezydent Izraela Reuven Rivlin, marszałkowie Sejmu i Senatu RP, prezydent Warszawy i delegacje państwowe. Szacuje się, że w uroczystości uczestniczyło ponad 1500 gości, z udziałem 600 dziennikarzy ${ }^{1}$.

$\mathrm{Na}$ oficjalnej stronie muzeum sformułowano jego misję w następujący sposób: „Przywracać i chronić pamięć historii Żydów polskich, przyczyniając się do wzajemnego zrozumienia i szacunku wśród Polaków i Żydów, społeczeństw Europy i świata”, oraz jak czytamy dalej: „Tworzyć nowoczesne muzeum, centrum edukacji i kultury, platformę dialogu społecznego - instytucję oferującą głębokie doświadczenie i promującą nowe standardy obcowania z historią”2. Dowiadujemy się także, jaki charakter ma mieć placówka:

Muzeum Historii Żydów Polskich jest pierwszą w Polsce instytucją publiczno-prywatną stworzoną wspólnie przez Ministerstwo Kultury i Dziedzictwa Narodowego, Miasto stołeczne Warszawę oraz Stowarzyszenie Żydowski Instytut Historyczny w Polsce. Na mocy aktu założycielskiego strona publiczna za kwotę $180 \mathrm{mln}$ złotych sfinansowała budowę budynku muzeum oraz pokrywa większość bieżącego budżetu. Stowarzyszenie zainicjowało projekt, odpowiadało za sfinansowanie oraz organizację procesu tworzenia wystawy stałej. Dzięki wsparciu donatorów

\footnotetext{
${ }^{1}$ http://www.polin.pl/pl/historia-od-idei-przez-ohel-do-muzeum-polin, dostęp: 20.03.2017.

${ }^{2}$ http://www.polin.pl/pl/o-muzeum/misja-i-wizja 2017, dostęp: 20.03.2017.
} 
z całego świata Stowarzyszenie zabrało na ten cel 145 mln złotych. Wspiera także działalność edukacyjną i publiczną muzeum - do tej pory przekazało na ten cel $20 \mathrm{mln}$ złotych”’3.

Wystawa główna obejmuje 1000 lat historii żydowskiej w Polsce. Składają się na nią następujące galerie:

- Las

- Pierwsze spotkania (960-1500)

- Paradisus Iudaeorum (1569-1648)

- Miasteczko (1648-1772)

- Wyzwania nowoczesności (1772-1914)

- Na żydowskiej ulicy (1918-1939)

- Zagłada (1939-1945)

- Powojnie (1944 do dziś)

Pomimo krótkiego okresu działalności placówka otrzymała już wiele nagród, między innymi Krzyż Oficerski Orderu Zasługi, medal Gloria Artis, Paszport Polityki, Oskar Polskiej Rady Biznesu, Finlandia Prize for Architecture (Kirshenblatt-Gimblet, 2015b: 2). Muzeum zyskało również prestiżowy tytuł European Museum of The Year 2016.

\section{Jakościowa analiza dyskursu}

W biuletynie Gminy Wyznaniowej Żydowskiej w Krakowie pt. Nasza Gmina możemy odnaleźć następującą wzmiankę: „Wystawę Główną - wielką multimedialną opowieść o tysiącu lat dziejów Żydów na ziemiach polskich, już przez pierwsze 3 dni po otwarciu odwiedziło około 15 tysięcy osób. Poświęcono jej ponad 2 tysiące krajowych materiałów prasowych, w mediach zagranicznych ukazało się prawie 300 wzmianek, większość w USA, Niemczech i Izraelu” (Podgórska, 2014: 4). Dane te zdają się usprawiedliwiać podjęcie decyzji o ograniczeniu materiału badawczego. Budowanie korpusu badawczego polegało na selekcji materiału od góry, tj. od ogółu do szczegółu (por. Wodak, Krzyżanowski, 2011: 60). W rezultacie na ów korpus składają się dwa ogólnopolskie czasopisma żydowskie: „Midrasz. Pismo Żydowskie” i „Chidusz. Magazyn Żydowski”. Są to renomowane żydowskie magazyny opiniotwórcze, wydawane w Polsce, w języku polskim. „Midrasz” jest żydowskim czasopismem społeczno-kulturalnym, ukazującym się od 1997 roku, skierowanym do czytelnika żydowskiego oraz do wszystkich zainteresowanych życiem

\footnotetext{
3 http://www.polin.pl/pl/partnerstwo-publiczno-prywatne, dostęp: 20.03.2017.
} 
Żydów w Polsce. Do 2009 roku był miesięcznikiem, obecnie rocznie ukazuje się sześć numerów, w których podejmowane są tematy „o żydowskiej historii, tradycji, tożsamości, o judaizmie, dialogu chrześcijańsko-żydowskim, o książce, filmie i muzyce, o polityce, Izraelu i tym wszystkim, co ważne jest dla Żydów żyjących w diasporze" 4 Z kolei miesięcznik gminy żydowskiej we Wrocławiu "Chidusz” ukazuje się od 2013 roku, przy tym większość artykułów z poszczególnych numerów dostępna jest także online ${ }^{5}$. Jest to bogato ilustrowany magazyn społeczno-kulturalny, w którym czytelnik odnajdzie wiele interesujących informacji o kulturze, sztuce i historii żydowskiej oraz bieżących wydarzeniach i problemach społecznych Żydów. Należy podkreślić, iż wiele portali żydowskich i biuletynów Gmin Żydowskich, także takie magazyny jak „Cwiszyn. Żydowski Kwartalnik o Kulturze i Sztuce” oraz „Miasteczko Poznań. Pismo społeczno-kulturalne”, również pisały o otwarciu muzeum, ale głównie były to krótkie komunikaty o charakterze informującym. Na łamach dwóch wybranych magazynów temu wydarzeniu poświęcono znacznie więcej miejsca, w kolejnych numerach w latach 2013-2016 zaprezentowano obszerne artykuły i wywiady z osobami tworzącymi lub repezentującymi tę instytucję. Uznałam zatem, że to właśnie ten głos, wizja autorów miała być dla redakcji „Midrasza” i „Chidusz” najbardziej akcentowaną i słyszalną społecznie. $\mathrm{W}$ ten sposób analiza dyskursu została ukierunkowana na perspektywę twórców wystawy głównej muzeum Polin i ich wypowiedzi zamieszczonych w wybranej prasie mniejszościowej. Można założyć także, że autorom łatwiej i swobodniej było wypowiadać się w czasopismach skierowanych głównie do czytelnika żydowskiego. Przedmiotem analizy stały się wypowiedzi udzielane bezpośrednio po uroczystym otwarciu oraz późniejsze, w tym głównie opublikowane w okresie rocznic powstania instytucji. W celu ustalenia jak najszerszego spectrum dyskursów odrębnemu zbadaniu należy poddać narracje z prasy polskiej. Co prawda, główne periodyki opiniotwórcze często wzmiankowały jedynie o otwarciu muzeum, ale na przykład tygodnik „Polityka” poświęcił temu wydarzeniu cały numer ${ }^{8}$.

Już pierwsza lektura tekstów prasowych dała podstawy do stwierdzenia, iż głos jest niejednorodny, wypowiedzi mają jednak kilka wspólnych centralnych kategorii, ukierunkowanych na tożsamość muzeum, identyfikację Żydów polskich oraz dylematy historii polsko-żydowskiej. Celem analizy było każdorazowo ustalenie intencji nadawcy, sposobów budowania strategii narracyjnej o założeniach

\footnotetext{
4 http://www.midrasz.pl/miesiecznik/onas, dostęp: 20.03.2017.

${ }^{5}$ http://www.chidusz.com/, dostęp 20.03.2017.

6 http://www.cwiszn.pl/pl/pages/show/otwarcie\%20muzeum, dostęp: 20.03.2017.

7 http://www.miasteczkopoznan.pl/node/377, dostęp: 20.03.2017.

8 „Polityka” 2014, nr 43, Powrót Żydów (okładka).
} 
i wizji muzeum, a także występowania lub niewystępowania charakterystycznych treści. Należy podkreślić, że pytania o kształt muzeum nierzadko pojawiały się również w sugestywnych tytułach nadawanych wywiadom przez redakcje (por. Teksty źródłowe). Pytania badawcze dotyczyły sposobów konstruowania wizerunku muzeum dla odbiorcy polskiego i żydowskiego. Czy twórcy mają wspólną wizję przedstawiania żydowskiej historii w Polin? Czy autorzy wystawy głównej są ukierunkowani na perspektywę polską/żydowską/polsko-żydowską? Czy muzeum jest instytucją bardziej polską czy żydowską? W jaki sposób muzeum pokazuje dylematy i kontrowersje historyczne? Czy Polin wpisuje się w pozytywną narrację o wielowiekowej koegzystencji Żydów i Polaków na ziemiach polskich? Jak twórcy godzą oczekiwania różnych grup społecznych wobec idei muzeum?

Aleksandra Grzymała-Kazłowska (2004: 21) stwierdza, iż „zainteresowanie dyskursem wiąże się z głębokimi przemianami społecznymi i wizją współczesnego świata jako społeczeństwa zdominowanego przez praktyki komunikacyjne oraz przekonaniem, że rzeczywistość jest konstruowana w procesach komunikacji”. Wedle tej samej autorki dyskurs możemy rozumieć jako strukturę (gdzie analizie podlega jego budowa, porządek dyskursu, elementy składowe, relacje, hierarchia); proces (działanie komunikacyjne, nieustannie konstruowane znaczenia, dynamiczny akt kreacji); poprzez pełnione funkcje: komunikacyjną, mentalną, interakcyjną (por. Grzymała-Kazłowska, 2004: 21). W analizie uwzględniano wszystkie trzy elementy, które moim zdaniem można potraktować holistycznie. Podjęta interpretacja lokuje się w socjologicznym ujęciu dyskursu, rozumianym jako rodzaj działania komunikacyjnego, forma interakcji symbolicznej, w której za pomocą języka odbywa się definiowanie i interpretowanie sytuacji. Analiza SAD koncentruje się także na sposobach budowania tożsamości, dążenia do korzystnej autoprezentacji oraz zmaganiach o uzyskanie władzy nad partnerem i skłonienia go do określonego działania (ibidem: 17). W tym przypadku chodzić może o stworzenie wizerunku grupy (społeczności żydowskiej i polskiej połączonej trudną wspólną historią), jak również wizerunku żydowskiej instytucji muzealnej.

Wśród odmian SAD wskazuje się często na tradycje poststrukturalistycznej teorii Michela Foucaulta, etnometodologii i analizy konwersacyjnej, teorii Ervinga Goffmana bądź interakcjonizmu symbolicznego. Dla celów pracy najtrafniejsze wydaje się odwołanie do dorobku symbolicznego interakcjonizmu, akcentującego dynamiczny proces interakcji jednostek, które negocjują znaczenia, dopasowują się wzajemnie i biorą aktywny udział w wyłanianiu się nowych zjawisk społecznych, natomiast „sieć czy też instytucja nie funkcjonują automatycznie z powodu swej dynamiki wewnętrznej czy wymogów systemowych, lecz 
dlatego że w różnych ich punktach ludzie coś robią, a to co robią, jest skutkiem sposobu, w jaki definiują sytuację, w której przyszło im działać" (Blumer, 2007: 18). To uczestnicy wnoszą ze sobą świat przedmiotów, zestawy znaczeń i schematy interpretacyjne.

Po lekturze wszystkich tekstów utworzony został tzw. klucz kategoryzacyjny, który w badaniach jakościowych, zdaniem Karoliny Szczepanik, ,jest sam w sobie swoistym wynikiem badania. Kolejne kategorie klucza stanowią bowiem kolejne opisywane $\mathrm{w}$ analizowanych tekstach tematy bądź pomniejsze aspekty tematów głównych. Jest więc on rodzajem listy zagadnień poruszanych w materiale badawczym, dążącej do uchwycenia ich maksymalnej różnorodności" (Szczepanik, 2012: 98). Następnie zdefiniowano kilku kategorii w kluczu. Kolejnym krokiem było dołączenie do wyników badań tabeli z cytatami pochodzącymi bezpośrednio $\mathrm{z}$ analizowanych artykułów, a następnie wykazanie w jaki sposób te teoretycznie zdefiniowane elementy są ze sobą połączone lub też wzajemnie się na siebie nakładają (por. Szczepanik, 2012: 100).

\section{Podstawowy klucz interpretacyjny}

\begin{tabular}{|l|l|}
\hline \multicolumn{1}{|c|}{ Przekaz } & \multicolumn{1}{c|}{ Kategoria 1. WYZNACZENIE MISJI } \\
\hline $\begin{array}{l}\text { Śdriadectwo } \\
\text { zdydodzenia } \\
\text { w Polsce }\end{array}$ & $\begin{array}{l}\text { Zagłada nie podsumowuje żydowskiego doświadczenia w Polsce. Galeria } \\
\text { powojenna i samo muzeum to wyraz odrodzenia tego życia (...). Muzeum } \\
\text { ogłasza światu, że rzeczywiście istnieje nowa Rzeczpospolita Polska, która } \\
\text { chce stawić czoło problemom i załatwić dawne rachunki”, M2, s. } 61 \text { i } 63 .\end{array}$ \\
& $\begin{array}{l}\text { „Dwadzieścia pięć lat temu bardzo wielu powątpiewało w sens życia } \\
\text { żyę utrzyma (...). Po 25 latach mogę śmiało powiedzieć, że tworzy się nowa } \\
\text { diaspora polska”, Ch7, s. 1, „Muzeum przynajmniej w moim zamyśle, miało } \\
\text { przekazać każdemu zwiedzającemu - że Żydzi byli między Polakami. } \\
\text { A kiedy już ktoś będzie o tym wiedział, to zacznie się zastanawiać, czy są } \\
\text { nadal, i postanowi ich poszukać. Odczucie pustki jest pierwszym krokiem. } \\
\text { A po nim być może ktoś zechce wrócić do Muzeum, zainteresować się } \\
\text { wkładem Żydów w budowanie wspólnej ojczyzny, poznać ich kulturę”, Ch7, } \\
\text { s. 2. } \\
\text { „Otwarcie wystawy stałej w Muzeum Polin to dla mnie fundamentalna } \\
\text { zmiana w przestrzeni polskiej diaspory żydowskiej”, Ch10, s. 1. } \\
\text { Podobny przekaz również w: Ch5, s. 1. }\end{array}$ \\
\hline
\end{tabular}




\begin{tabular}{|c|c|}
\hline $\begin{array}{l}\text { Przypominanie } \\
\text { historii polsko- } \\
\text {-żydowskiej }\end{array}$ & $\begin{array}{l}\text { „Jednym z celów Muzeum jest więc przynajmniej pośrednio odzyskanie dla } \\
\text { zbiorowej świadomości długiej historii Polski jako kraju różnorodnego } \\
\text { pod względem kulturowym i religijnym. Skupienie w Muzeum uwagi na } \\
\text { Żydach nie tylko konkretyzuje podstawowy postulat tej nowej metahistorii. } \\
\text { Na płaszczyźnie praktycznej jest to także gest ze strony Polski zmierzający } \\
\text { do rozliczenia się z Żydami poprzez próbę stawienia czoła skomplikowanej } \\
\text { przeszłości”, M2, s. 59. } \\
\text { „Polin ma przypominać Polakom i Żydom, że historia polskich Żydów to } \\
\text { ich historia. Nieżydowskim Polakom pokazujemy, że to integralna, ważna } \\
\text { część historii Polski, a niepolskim Żydom, że polski rozdział to kluczowa } \\
\text { część historii diaspory, narodu żydowskiego", Ch11, s. 14. } \\
\text { "Jedyne duże muzeum w Polsce, które opowiada tysiąc lat historii Polski, } \\
\text { nie tylko Żydów”, Ch4, s. 2-3. }\end{array}$ \\
\hline $\begin{array}{l}\text { Wielka Opowieść } \\
\text { o polskich Żydach }\end{array}$ & $\begin{array}{l}\text { „Chciałbym, żeby tu, na tym miejscu, powstało muzeum, które sprawi, że } \\
\text { Polska nie będzie się kojarzyła tylko z Zagładą, ale będzie opowiadało o tym, } \\
\text { jak Żydzi żyli wcześniej i później” (...) „Chcielibyśmy, żeby i nasze muze- } \\
\text { um było miejscem dopełniającym opowieść o życiu polskich Żydów”, M1, } \\
\text { s. 14-15. } \\
\text { „To nie jest przekaz przeciwko komukolwiek, ale opowieść o różnorodno- } \\
\text { ści Żydów i kolejach żydowskiego życia w powojennej Polsce. Pokazujemy } \\
\text { emigrację i asymilację, komunistów i syjonistów, Żydów religijnych i antyre- } \\
\text { ligijnych, kulturę tworzoną w jidysz, po hebrajsku i po polsku. Cała wystawa } \\
\text { jest taka. A przy okazji wychodzi historia Polski, która na razie nie jest } \\
\text { pokazana nigdzie indziej”, Ch6, s. } 6 \text {. }\end{array}$ \\
\hline $\begin{array}{l}\text { Nowa narracja } \\
\text { historyczna } \\
\text { w Polsce }\end{array}$ & $\begin{array}{l}\text { „Mój kontakt z Muzeum i jego zespołem ugruntował mnie w przekonaniu, } \\
\text { że wystawa główna będzie umiejscowiona w ramach nowej metahisto- } \\
\text { rii, wyłonionej z badań nad historią polsko-żydowską, których odnowie- } \\
\text { nie nastąpiło w latach } 70 \text {. XX wieku i urosło do imponujących rozmiarów, } \\
\text { w miarę jak Polska skutecznie odrzuciła komunizm i wkroczyła na drogę de- } \\
\text { mokratyzacji”, M2, s. 58; Rzuca wyzwanie zarówno Polakom, jak i Żydom, } \\
\text { aby potraktowali na serio nową metahistorię, jaka wyłoniła się z ostatnich } \\
\text { trzydziestu czy czterdziestu lat badań, podważając niektóre głęboko zakorze- } \\
\text { nione stereotypy i przekonania”, M2, s. } 63 \text {. } \\
\text { „Odwołuje się do bardzo mocnego współcześnie w Polsce trendu szukania } \\
\text { innych narracji tożsamościowych. To muzeum przedstawia taką inna nar- } \\
\text { rację. O Żydach, którzy są całkowicie żydowscy i jednocześnie są całkowi- } \\
\text { cie polscy. Są polskimi Żydami, są Polakami”, Ch4, s. } 2 \text {. }\end{array}$ \\
\hline
\end{tabular}




\begin{tabular}{|c|c|}
\hline Przekaz & Kategoria 2. TOŻSAMOŚĆ MUZEUM \\
\hline $\begin{array}{l}\text { Polsko-żydowskie ze } \\
\text { swej natury }\end{array}$ & $\begin{array}{l}\text { „Muzeum daje do zrozumienia, że nie ma żydowskiego doświadczenia } \\
\text { bez zanurzenia się w Polsce, w jej gestalt, zwłaszcza izraelskim uczniom } \\
\text { i innym grupom wycieczkowym; wcześniej byli odgrodzeni od polskiego } \\
\text { otoczenia”, „to wydaje się błędne, a nawet obraźliwe dla wielu myślących } \\
\text { Polaków”, (...) „Muzeum umiejscawia Żydów mocno w Polsce, pokazuje } \\
\text { jak bardzo byli jego częścią”, M2, s. } 59 . \\
\text { „Nie można opowiadać osobno historii Polski i historii Żydów. Obie } \\
\text { nie są pełne bez siebie nawzajem. Nie można zrozumieć historii polskich } \\
\text { Żydów bez szerokiego kontekstualizowania jej w wydarzeniach, które nie- } \\
\text { ustannie na Żydów oddziaływały. Dlatego wystawa opowiada o lokacji } \\
\text { miast, elekcjach królów, rozbiorach czy wojnach” (...) „jeśli po przejściu } \\
\text { tej ekspozycji ktoś uważa, że «Kołacz Królów» opowiada historię Polski, } \\
\text { a nie historię Żydów, to być może wynika to z bardzo powierzchownej } \\
\text { reakcji na trzy portrety. Można pomyśleć o trzech zaborcach, o pustym } \\
\text { królewskim tronie i przejść dalej z poczuciem dominacji narracji polskiej } \\
\text { nad żydowską. Każdy zwiedzający ma oczywiście prawo do własnej inter- } \\
\text { pretacji, nawet jeśli gwałci ona przekaz wystawy. Ale trudno za to winić } \\
\text { wystawę. Trudno też zgodzić się, że «polska» perspektywa dominuje nad } \\
\text { perspektywą «żydowską», Ch8, s. 2. }\end{array}$ \\
\hline
\end{tabular}




\begin{tabular}{|c|c|}
\hline $\begin{array}{l}\text { Wyjście poza dycho- } \\
\text { tomię }\end{array}$ & $\begin{array}{l}\text { „To przede wszystkim instytucja międzynarodowa i historyczna. Oczy- } \\
\text { wiście jest to polskie muzeum, które znajduje się w Polsce i opowiada } \\
\text { o polskich Żydach. Ale placówka ta nie jest muzeum żydowskim w trady- } \\
\text { cyjnym znaczeniu, które nie ma racji bytu na gruncie europejskim, gdzie } \\
\text { wiele z tak zwanych muzeów żydowskich jest muzeami państwowymi”, } \\
\text { Ch5, s. } 1 \text {. } \\
\text { „Sama opozycja jest fałszywa i wynika z ideologicznych założeń, które } \\
\text { wystawa MHŻP odrzuciła. Nie ma dwóch perspektyw - polskiej i ży- } \\
\text { dowskiej. Wiara, że istnieją „dwie prawdy”, a narracja historyczna musi } \\
\text { komuś służyć i kogoś uprzywilejowywać, to typowe zawłaszczanie histo- } \\
\text { riografii przez politykę. Czy nie należy raczej zapytać o to, czy narracja } \\
\text { jest przekonująca i rzetelna, a nie: komu ona służy i kogo uprzywilejo- } \\
\text { wuje?”, Ch8, s. 1. } \\
\text { „To nie jest przekaz przeciwko komukolwiek, ale opowieść o różnorod- } \\
\text { ności Żydów i kolejach żydowskiego życia w powojennej Polsce” Ch6, } \\
\text { s. 5-6. }\end{array}$ \\
\hline $\begin{array}{l}\text { W kierunku per- } \\
\text { spektywy żydowskiej }\end{array}$ & $\begin{array}{l}\text { „Skoro jest to muzeum o Żydach, to chodzi o żydowski ogląd poszcze- } \\
\text { gólnych wydarzeń historycznych, pokazanie, jak Żydzi je postrzegali. } \\
\text { (...) Mówimy dokumentami z epoki, pokazujemy kontekst, polemiki, } \\
\text { niemniej jednak podmiotem opowiadanej historii są Żydzi i ich punkt } \\
\text { widzenia” (...) „Żydzi są podmiotem naszej wystawy, świat tam poka- } \\
\text { zany, lata Polski Ludowej, widziany jest przede wszystkim żydowskimi } \\
\text { oczyma. Aczkolwiek zdaję sobie sprawę, że tworzyli to muzeum bar- } \\
\text { dzo różni ludzie i tak naprawdę nie ma mowy o jednej perspektywie”, } \\
\text { M3, s. } 8 \text {. }\end{array}$ \\
\hline $\begin{array}{l}\text { Bardziej polskie ze } \\
\text { swej natury }\end{array}$ & $\begin{array}{l}\text { „Przeogromnie bawi mnie, jak wściekle polskie jest to muzeum. Na wy- } \\
\text { stawie świata zewnętrznego prawie w ogóle nie ma. Pojawia się dwa razy. } \\
\text { W galerii średniowiecznej, żeby pokazać, skąd Żydzi przyjechali, i w galerii } \\
\text { nowoczesnej, żeby pokazać, dokąd wyjeżdżali (...). Nie sądzę, aby było to } \\
\text { intencjonalnie zaprojektowane, tak po prostu wyszło. Ale to co wyszło, } \\
\text { jest bardzo autentyczne, jeśli chodzi o polską i żydowską autopercep- } \\
\text { cję”, Ch10, s. } 3 \text {. }\end{array}$ \\
\hline $\begin{array}{l}\text { Jednak bardziej } \\
\text { polskie }\end{array}$ & $\begin{array}{l}\text { „Wszystko jest opowieścią polską, sprowadzoną do jednego mianownika, } \\
\text { wyrównującą, tu nie ma miejsca na inność”, M3, s. } 10 \text {. }\end{array}$ \\
\hline
\end{tabular}




\begin{tabular}{|c|c|}
\hline Przekaz & Kategoria 3. TOŻSAMOŚĆ ŻYDÓW OBECNYCH NA WYSTAWIE \\
\hline $\begin{array}{l}\text { Poszukiwanie kryteriów } \\
\text { tożsamościowych }\end{array}$ & $\begin{array}{l}\text { „My mamy dość jasno sprecyzowaną strategię pokazywania kwestii } \\
\text { tożsamościowych. Nie nazywamy Żydami ludzi, którzy nigdy o tym } \\
\text { nie mówili publicznie albo którzy się za Żydów nie uważali. O tożsamo- } \\
\text { ści Żydzi mówią swoim własnym językiem”, M1 s. } 17 \text {. } \\
\text { „Chcemy, żeby zwykli, przeciętni Żydzi byli równie ważnym elemen- } \\
\text { tem narracji, jak ci wybitni. Opisujemy jakiś trend, np. emigrację, i po- } \\
\text { kazujemy nie kogoś znanego, ale zwyczajne osoby”, Ch6, s. } 5 \text {. } \\
\text { „Proces deasymilacji (...) chcieliśmy pokazać na końcu, retrospek- } \\
\text { tywnie, na wystawie po } 1989 \text { roku. To oni opowiedzą o tym, pokażą } \\
\text { momenty, w których dowiedzieli się, że mają żydowskie korzenie, bądź } \\
\text { też zechcieli być Żydami. Przywiązywaliśmy do tego ogromną wagę. } \\
\text { Niestety ta część jest bardzo okrojona”, M3, s. } 6 \text {. }\end{array}$ \\
\hline $\begin{array}{l}\text { Oczekiwania społecz- } \\
\text { ne wobec tożsamości } \\
\text { Żydów obecnych na } \\
\text { wystawie }\end{array}$ & $\begin{array}{l}\text { „Żebyśmy tych Żydów w jakiś sposób «wydobywali z ukrycia». Są- } \\
\text { dzę jednak, że nie byłoby dobrze, gdyby do naszej galerii ludzi pchała } \\
\text { ciekawość, kto jest Żydem...” (...) Jednocześnie wiemy, co przyświeca } \\
\text { ludziom, którzy dokonują oceny naszej wystawy: chodzi im o kształto- } \\
\text { wanie świadomości Polaków, którzy często nie wiedzą, że jacyś ważni } \\
\text { artyści, filmowcy, malarze, pisarze, naukowcy, zasłużeni dla polskiej } \\
\text { kultury, są Żydami i dokonali wspaniałych osiągnięć. Upraszczając bar- } \\
\text { dzo, chcą oni, by ludzie zdali sobie sprawę z tego, jak wielki wkład } \\
\text { w polską kulturę mieli Żydzi”, M1, s. } 19 \text {. } \\
\text { "Julian Tuwim i Adam Michnik jako ideał uczestnictwa Żydów w pol- } \\
\text { skiej kulturze i historii” (...) To co Polaków (oczywiście chodzi o Pola- } \\
\text { ków „dobrze myślących”), zdaniem władzy, interesuje, to Żyd podobny. } \\
\text { Żyd niepodobny jest trudny, niezrozumiały, może niebezpieczny”, M3, } \\
\text { s. } 7 \text {. } \\
\text { „Niektórzy z naszych ważnych i zasłużonych sponsorów wyobrażali } \\
\text { sobie, że wspierają Muzeum w którym będzie pokazywane, jak wspa- } \\
\text { niali byli niektórzy Żydzi i dzięki temu żydowska duma zostanie } \\
\text { podbudowana. Byli też sponsorzy instytucjonalni, którzy chcieli, aby } \\
\text { Muzeum pokazywało, jak bardzo Żydzi mogą przysłużyć się polskiej } \\
\text { racji stanu. Ani jedno, ani drugie nie było naszym punktem wyjścia”, } \\
\text { Ch6, s. } 6 \text {. }\end{array}$ \\
\hline
\end{tabular}




\begin{tabular}{|c|c|}
\hline Przekaz & DOWSKI \\
\hline $\begin{array}{l}\text { Zbyt skromna gale- } \\
\text { ria po } 1989 \text { roku }\end{array}$ & $\begin{array}{l}\text { „Zabrakło czasu, ale też woli, żeby przedstawić należycie współczesność”, } \\
\text { M3, s. } 6 \text {. } \\
\text { „Nie jesteśmy w pełni zadowoleni z obecnego kształtu, ale pracujemy } \\
\text { nad poprawą. Wywiady z przedstawicielami kilku współczesnych pokoleń } \\
\text { Żydów polskich w tej części wystawy mają za zadanie dać poczucie tego, } \\
\text { co dzieje się teraz (...) Jeszcze nie wszystko jest skończone. Pięciominuto- } \\
\text { wy film jak dotąd nie ma wersji ostatecznej. Odrzuciliśmy już trzy jego po- } \\
\text { przednie propozycje. Pokazywały życie żydowskie jak cepeliadę, jakbyśmy } \\
\text { żyli w wigwamach” s. } 4 \text { (...) „Jesteśmy dopiero na początku drogi, świeżo po } \\
\text { otwarciu. Niech to trochę ostygnie, trochę się ułoży, sprawdzimy to za pół } \\
\text { roku (...) Poczekajmy na odzew zwiedzających, aby móc te przestrzenie } \\
\text { zaprojektować w dialogu ze zwiedzającymi”, Ch7, s. 4-5. } \\
\text { „Ostatniej galerii w ogóle nie ma. Jesteśmy za blisko tych czasów i nie } \\
\text { mamy pomysłu, jak je pokazać. (...) Sam fakt, że Żydzi są, to trochę za mało, } \\
\text { żeby zbudować galerię. Wiem, że teraz trwają jakieś rozpaczliwe próby do- } \\
\text { czepienia w tej ostatniej przestrzeni czegoś, co nie będzie kiepskim filmi- } \\
\text { kiem promocyjnym, ani gadającymi głowami. I choć łatwo krytykować tę } \\
\text { ostatnią część, to sam nie mam pomysłu, jak mogłaby wyglądać”, Ch10, s. } 3 . \\
\text { Podobny przekaz również w: Ch6, s. 2. }\end{array}$ \\
\hline $\begin{array}{l}\text { Inna przestrzeń } \\
\text { w galerii po } 1989 \\
\text { roku }\end{array}$ & $\begin{array}{l}\text { „Nie do końca tak jest. Przede wszystkim wydarzenia po } 1989 \text { roku zajmują } \\
\text { najbardziej wyjątkową przestrzeń. To wysokie pomieszczenie, które sięga od } \\
\text { piwnicy po sam dach, w ciągu dnia wypełnia je piękne światło. Otwarta prze- } \\
\text { strzeń, która oddaje ducha lat po odzyskaniu niepodległości (...). Jeśli chodzi } \\
\text { o rozmiar, wysokość i dramatyzm, przebija wszystkie pozostałe, Ch5, s. 2. }\end{array}$ \\
\hline $\begin{array}{l}\text { POLIN jako forum } \\
\text { dla społeczności } \\
\text { żydowskiej }\end{array}$ & $\begin{array}{l}\text { „Mam nadzieję, że w tej materii będziemy umieli ze sobą współpracować, } \\
\text { choćby tak jak staramy się współpracować z Centrum Kultury Jidysz na Mu- } \\
\text { ranowie”, s. } 21 \text { (...) „mamy trochę inne zadania [z ŻIH] i dlatego chciała- } \\
\text { bym, byśmy mogli ze sobą bliżej współpracować”, M1, s. 21-22. } \\
\text { „W żadnym wypadku Polin nie może być instytucją, która ma reprezen- } \\
\text { tować polskich Żydów”, Ch7, s. 3; „Mam nadzieję, że muzeum stanie się } \\
\text { miejscem spotkań i porozumienia. Ale ono nie zastąpi żadnej organizacji” } \\
\text { (...). W ŻIH są autentyczne dokumenty i skarby wpisane na Listę Dziedzi- } \\
\text { ctwa Światowego UNESCO, Ch7, s. } 4 \text {. } \\
\text { „Mam nadzieję, że to Muzeum będzie jak duży namiot. Neutralne miejsce } \\
\text { spotkań, w takim znaczeniu, że nie będzie tu dochodzić do konfliktów (...). } \\
\text { Miejsce, gdzie polscy Żydzi będą chcieli rozmawiać” Ch5, s. } 8 \text {. }\end{array}$ \\
\hline
\end{tabular}




\begin{tabular}{|c|c|}
\hline Przekaz & Kategoria 5. KONTROWERSJE \\
\hline $\begin{array}{l}\text { Relacje polsko- } \\
\text {-żydowskie bez } \\
\text { manipulacji }\end{array}$ & $\begin{array}{l}\text { „Przewodnią myślą tej nowej metahistorii - i wystawy głównej w Mu- } \\
\text { zeum - jest to, że związki Polski z jej Żydami wyrażały się poprzez } \\
\text { całą gamę postaw i zachowań. Razem łączyły się w złożony rachunek } \\
\text { przyczyn i skutków, zróżnicowanych motywów i nieprzewidzianych } \\
\text { konsekwencji” (...). Najlepszą metaforą dla większej części polsko- } \\
\text {-żydowskiej symbiozy jest "małżeństwo z rozsądku” (...). Muzeum } \\
\text { kształtuje takie przesłanie, ani romantyczne, ani demoniczne ujęcie, ale } \\
\text { próba ukazania niezwykle złożonego, pełnego świateł i cieni związku”, } \\
\text { M2, s. } 60 \text {. }\end{array}$ \\
\hline Negocjowanie & $\begin{array}{l}\text { „Choć łatwo zauważyć, że podczas gdy pozytywne czy neutralne aspek- } \\
\text { ty życia Żydów w Polsce są mocno widoczne, antysemityzmu, dyskry- } \\
\text { minacji czy pogromów trzeba nieco bardziej poszukać (...) na obronę } \\
\text { tego stanowiska, które zapewne było także politycznie wymuszone, } \\
\text { istnieje bardzo merytoryczny argument - dla znacznego procenta pol- } \\
\text { skich Żydów przez większość czasu, kiedy żyli w Polsce, istotne ele- } \\
\text { menty pozytywne i neutralne przeważały, choć głównie dlatego, że nie } \\
\text { byli oni wówczas dopuszczeni do tych obszarów społecznych, gdzie } \\
\text { mogliby spotkać się z antysemityzmem. To doświadczenie stało się } \\
\text { powszechne razem ze zniesieniem prawnych barier społecznych (...). } \\
\text { Natomiast istotnie jest to adekwatna reprezentacja rzeczywistości”, } \\
\text { Ch10, s. 1. } \\
\text { Przy ekspertyzach z Ministerstwa Kultury są „pewne kontrowersje, które } \\
\text { dotyczą nie spraw merytorycznych, ale interpretacji i wspomnianego zniu- } \\
\text { ansowania. Dotyczą one zwłaszcza galerii powojennej (...). Toczące się } \\
\text { obecnie rozmowy to jest właśnie próba znalezienia równowagi między } \\
\text { perspektywą wewnątrz żydowską a perspektywą wynikającą z tego, jaka } \\
\text { jest świadomość w społeczeństwie polskim”, M1, s. 17. } \\
\text { „Oczywiście koledzy historycy zgłaszali różne uwagi, wskazując, że pewne } \\
\text { fragmenty wystawy można by zrobić inaczej, ale są to naturalne róż- } \\
\text { nice perspektyw, a nie fundamentalna niezgoda. Dzięki temu muzeum } \\
\text { nie tylko się podoba, ale budzi zaufanie, a to jest najważniejsze”, Ch11, } \\
\text { s. 16. }\end{array}$ \\
\hline $\begin{array}{l}\text { Manipulacja } \\
\text { historyczna }\end{array}$ & $\begin{array}{l}\text { „Lęk przed otwarciem był tak duży, że należało przedsięwziąć środki zarad- } \\
\text { cze, wprowadzić korekty, żeby w ekspozycji nie znalazło się coś, co bije po } \\
\text { oczach i żeby utrzymana była dobra atmosfera”, M3, s. } 9 \text {. }\end{array}$ \\
\hline
\end{tabular}




\begin{tabular}{|c|c|}
\hline Naciski sponsorów & $\begin{array}{l}\text { „Aby wystawa powojenna przedstawiała historię bardziej budująca, kon- } \\
\text { centrowała się na dużych i znanych nazwiskach, przede wszystkim tych Ży- } \\
\text { dów, którzy wnieśli wkład w kulturę polską” (...). Te naciski spotykały się ze } \\
\text { zrozumieniem w Polsce. „Po pierwsze, mówiono sobie, skoro dają pieniądze, } \\
\text { i to duże pieniądze, to mają prawo oczekiwać. Po drugie, dzieje Żydów zasymi- } \\
\text { lowanych były bardziej zrozumiałe i atrakcyjne także dla Polaków”, M3, s. 5-6, } \\
\text { Podobny przekaz również w: Ch6, s. 5-6 (por. tabela: Tożsamość Żydów } \\
\text { obecnych na wystawie, kategoria: Oczekiwania społeczne wobec tożsamości } \\
\text { Żydów obecnych na wystawie) }\end{array}$ \\
\hline Naciski polityczne & $\begin{array}{l}\text { „W maju } 2013 \text { roku w Ministerstwie Kultury zakomunikowano wprost, że nasza } \\
\text { galeria (powojenna) jest niezgodna z polską racją stanu, a Muzeum jest przecież } \\
\text { robione za polskie pieniądze” (...). „A przede wszystkim za mało jest o Ży- } \\
\text { dach, jak to elegancko sformułowano, "podobnych do naszych przyjaciól», } \\
\text { czyli zasymilowanych, takich, z których możemy być dumni”, M3, s. 7. } \\
\text { „Pojawiły się pod koniec, co mnie zresztą wcale nie zaskoczyło. Jednak } \\
\text { ocenę wystawy powierzono osobom mającym dobrą wolę, w znacznej } \\
\text { części historykom, którzy są najlepszymi znawcami epoki. Niektóre } \\
\text { zmiany były korzystne. Dla mnie najważniejsze jest, że podmiana kilku } \\
\text { cytatów i osłabienie w dwóch czy trzech punktach narracji o antyżydow- } \\
\text { skich postawach Polaków nie zmieniło w zasadzie wydźwięku i zamierzo- } \\
\text { nego przekazu”, Ch6, s. } 5 \text {. } \\
\text { „Muzeum nie jest instytucją żydowską, ale polską instytucją państwową } \\
\text { podlegającą presjom politycznym, i to nie może dziwić, bo tak dzieje się } \\
\text { z każdą placówką w każdym kraju”, Ch10, s. } 3 \text {. }\end{array}$ \\
\hline $\begin{array}{l}\text { Zapewnienie swo- } \\
\text { body interpretacji } \\
\text { i wielości perspek- } \\
\text { tyw }\end{array}$ & $\begin{array}{l}\text { Ważna jest kwestia swobody interpretacji; pracował międzynarodowy ze- } \\
\text { spół historyków: „chcieliśmy spojrzeć na historię szerzej, z różnych punk- } \\
\text { tów widzenia”, M1, s. } 15 \text { (...). „Posługujemy się różnymi perspektywami } \\
\text { interpretacyjnymi. Pokazujemy stanowiska trzech głównych sił politycznych } \\
\text { i niezależnego intelektualisty, i te interpretacje zestawiamy ze sobą”, M1, s. } 16 . \\
\text { „Wybór perspektywy za każdym razem był wynikiem refleksji wie- } \\
\text { lu wybitnych badaczy, wśród nich i takich, dla których kontekst "pol- } \\
\text { ski» nigdy nie był najważniejszy”(...). „Nie ma jednej odpowiedzi na } \\
\text { to, jaką historię opowiada Polin, jacy są polscy Żydzi, jaka jest ta histo- } \\
\text { ria. Jeżeli jakieś muzeum dostarcza jednej odpowiedzi, to oznacza, } \\
\text { że jest złe, nudne, że jest to muzeum na jedne odwiedziny”, Ch8, s. } 3 . \\
\text { „Nigdy nie zależało nam na stworzeniu narracji, w której będzie trzeba po- } \\
\text { dążać jedną ścieżką i postrzegać ją w jeden określony sposób. Jesteśmy ot- } \\
\text { warci na interpretację. Pojawia się więcej niż jeden głos, więcej niż jedna } \\
\text { perspektywa” Ch5, s. } 7 \text {. } \\
\text { Podobny przekaz również w: Ch6 s. } 3 \text {. }\end{array}$ \\
\hline
\end{tabular}


Brak swobody interpretacji, narracja zamknięta
„Obecna narracja muzealna nie pozwala stawiać żadnych pytań. Bo od razu pojawia się niepokój: jak nas zobaczą, co o nas pomyślą? Takie obawy, także te żydowskie, że po co stawiać sprawy tak ostro, nie pozwalają na działania edukacyjne, ważne dla naszej cywilizacji” (...). „Muzeum dzisiaj służy utrwalaniu opowieści, która nie służy zmianie i jest alibi dla państwa polskiego. Że jest dobrze, a Muzeum jest najlepszym tego dowodem”, M3, s. 10.

\begin{tabular}{|c|c|}
\hline Przekaz & Kategoria 6. JAKOŚĆ MUZEUM \\
\hline $\begin{array}{l}\text { Liczby, skala zain- } \\
\text { teresowania }\end{array}$ & $\begin{array}{l}\text { „Uczestniczyłam w kilku debatach i byłam zdumiona, że ludzie siedzieli na- } \\
\text { wet na schodach”(...). W ciągu samej Nocy Muzeów odwiedziło nas } 6 \text { tys. } \\
\text { osób”, M1, s. } 22 \text {. } \\
\text { „Wydaje mi się, że będzie to muzeum przełomowe pod wieloma wzglę- } \\
\text { dami. To nie znaczy, że jest bezbłędne. Jestem krytyczny, przynajmniej co } \\
\text { do kilku rozwiązań, może najbardziej tych zastosowanych w galerii, którą } \\
\text { projektowałem - ona jest mi najbliższa. A jednak to przełomowa wystawa, } \\
\text { bo w spektakularny sposób pokazuje setkom tysięcy ludzi, którzy będą ją } \\
\text { oglądać, coś, co jest już obecne w polskiej kulturze, ale nadal świadomością } \\
\text { dość elitarną i wąską”, Ch4, s. } 2 \text {. } \\
\text { „Pierwszym sygnałem, że muzeum to naprawdę coś wyjątkowego, była nie- } \\
\text { zwykła fala zainteresowania mediów”; „To przekroczyło nasze najśmielsze } \\
\text { oczekiwania. W ciągu kilku tygodni odnotowaliśmy pięć tysięcy przychyl- } \\
\text { nych, a często entuzjastycznych komentarzy w prasie, telewizji, radio i na } \\
\text { internetowych portalach informacyjnych - w Polsce i na całym świecie, } \\
\text { w tym w najważniejszych tytułach prasy o zasięgu międzynarodowym, jak } \\
\text { The Economist czy New York Times”(...). „Od dnia otwarcia muzeum do- } \\
\text { słownie ustawiały się kolejki chcących zobaczyć wystawę, przez pierwsze } \\
\text { dwa miesiące przeszło przez nią blisko } 70 \text { tys. ludzi”(...). Od otwarcia } \\
\text { muzeum łącznie odnotowaliśmy już } 1,5 \text { mln gości”, Ch11, s. 14. } \\
\text { Podobny przekaż również w: Ch9, s. } 1 \text {. }\end{array}$ \\
\hline $\begin{array}{l}\text { Kwerendy, wie- } \\
\text { loletnie badania } \\
\text { poprzedzające }\end{array}$ & $\begin{array}{l}\text { „Wieloletnie zbieranie funduszy na uruchomienie muzeum sprawiło, że jego } \\
\text { twórcy mieli dużo czasu na refleksje i prowadzenie badań (...) dzięki temu } \\
\text { muzeum jest dobrze przemyślane, oparte na mocnym intelektualnym fun- } \\
\text { damencie”, Ch11, s. } 16 \text {. } \\
\text { „Ogólny plan wystawy zaczął wyłaniać się w } 2000 \text { roku, ale jeśli weźmie- } \\
\text { my pod uwagę, że opracowywanie materiałów zaczęliśmy już w } 1997 \text { roku, } \\
\text { oznacza to prawie dwie dekady przygotowań”, Ch9, s. } 1 \text {. } \\
\text { „Muzeum powstawało tak długo również dlatego, że wielu historyków było } \\
\text { zaangażowanych nie tylko w tworzenie opowieści, ale też w pogłębianie } \\
\text { badań historycznych tam, gdzie podczas konstruowania narracji dowie- } \\
\text { dzieliśmy się, że nie wiemy rzeczy, które wydawało się, że musimy wiedzieć } \\
\text { o dziejach Żydów polskich”, Ch4, s. } 3 \text {. } \\
\text { Podobny przekaz również w: M3, s. } 5 \text {. }\end{array}$ \\
\hline
\end{tabular}




\begin{tabular}{|c|c|}
\hline $\begin{array}{l}\text { ytet naukowy, } \\
\text { zenci }\end{array}$ & $\begin{array}{l}\text { „Na różnych etapach prac na poszczególnymi galeriami nasze działania } \\
\text { były recenzowane. (...) Oprócz tego poszczególne prace weryfikowała } \\
\text { też Rada Muzeum. Żadna z tych kontroli nie wykazała nam błędów me- } \\
\text { rytorycznych, M1, s. 16-17. } \\
\text { „Za każdym razem międzynarodowa grupa historyków podejmowała } \\
\text { decyzje, w jaki sposób najtrafniej spleść te różne wątki, które z nich były } \\
\text { dominujące dla tego, co w naszej sytuacji uznaliśmy za główną narrację hi- } \\
\text { storii Żydów polskich”, Ch8, s. } 2 \\
\text { „Gigantyczne dzieło moich poprzedników, dużego zespołu historyków } \\
\text { i kuratorów, okazało się solidne i wiarygodne, nie zawiera ani istotnych błę- } \\
\text { dów, ani wypaczeń historycznych”, Ch11, s. 16. }\end{array}$ \\
\hline Nagrody & $\begin{array}{l}\text { „W jury obydwu nagród zasiadają wybitni eksperci muzealnicy (...). Kon- } \\
\text { kurencja była bardzo duża (...). Do tej pory ani jedno z polskich muzeów } \\
\text { nie otrzymało żadnej z tych nagród, a Polin dostało od razu obydwie” } \\
\text { (...). To buduje naszą pozycję w środowisku muzealnym w Polsce i Eu- } \\
\text { ropie” (...). To rozwiewa też wątpliwości, bo Polin powstało „niemal bez } \\
\text { zbiorów, nasza kolekcja dopiero się tworzy - głównie dzięki pamiątkom } \\
\text { przekazywanym w darze przez osoby prywatne”, Ch11, s. } 16 \text {. } \\
\text { „Oczywiście nie mogę pominąć też wyróżnień i nagród, które w tym roku } \\
\text { otrzymaliśmy (...). Każde wyróżnienie i dobre słowo było dla nas tym jedy- } \\
\text { nym i najważniejszym” Ch9, s. } 2-3 \text {. }\end{array}$ \\
\hline $\begin{array}{l}\text { Muzeum narracyjne } \\
\text { a problem braku } \\
\text { obiektów }\end{array}$ & $\begin{array}{l}\text { „Wówczas najnowszym pomysłem były muzea narracyjne, opowiadające histo- } \\
\text { rię nie przez zestawienie informacji, ale poprzez tworzenie wątków, trochę } \\
\text { tak jak w filmie czy serialu” (...). „Spotykamy się z zarzutami, że mamy w mu- } \\
\text { zeum zbyt mało obiektów. Tymczasem nie jest ich tak mało, bo około dwustu, } \\
\text { ale dla nas każdy z tych obiektów musi stanowić część narracji”, M1, s. } 15 \text {. } \\
\text { „Nasza kolekcja dopiero się tworzy, dzięki pamiątkom przekazywanym } \\
\text { w darze”, Ch11, s. } 16 \text {. } \\
\text { „Do tej opowieści gromadzi się dopiero obiekty. Podstawowym zagroże- } \\
\text { niem muzeum narracyjnego, o którym od początku wiedzieliśmy i którego } \\
\text { chyba nie zawsze dało się uniknąć, jest problem braku obiektów”, Ch4, s. 1. }\end{array}$ \\
\hline Multimedialność & $\begin{array}{l}\text { „Bronimy się jakością (...). Wystawa jest multimedialna w szerokim wy- } \\
\text { miarze: poprzez scenografię, staranny dobór zdjęć, poprzez obiekty, które } \\
\text { doskonale wpisują się w narrację, poprzez dźwięk. Tworzy się dzięki temu } \\
\text { pełne doświadczenie”, M1, s. } 15 \text {. } \\
\text { „Stworzyliśmy tę wystawę w taki sposób, że jeśli mieliśmy coś ważnego do } \\
\text { zakomunikowania, informacja o tym pojawia się kilka razy: w tekście, jako } \\
\text { ilustracja, w formie projekcji, eksponatu (...). Przekaz, który osiągamy, } \\
\text { wynika z połączenia różnych elementów. Niektórzy wolą przeczytać tekst } \\
\text { niż obejrzeć film, inni nie zwracają w ogóle uwagi na eksponaty, przecho- } \\
\text { dząc bezpośrednio do tekstów”, Ch5, s. } 4-5 \text {. }\end{array}$ \\
\hline
\end{tabular}




\begin{tabular}{|c|c|}
\hline Przekaz & Kategoria 7. ODBIORCA W MUZEUM \\
\hline $\begin{array}{l}\text { Sprowokowany } \\
\text { do myślenia }\end{array}$ & $\begin{array}{l}\text { „Zależy nam żeby sprowokować widza do pewnych przemyśleń, do zasta- } \\
\text { nowienia się, jak ja bym się zachował, gdyby na progu mojego domu stanął } \\
\text { człowiek, który mnie prosi o pomoc, a wiedziałbym, jaka mi za to grozi kara,, } \\
\text { M1, s. } 16 \text {. } \\
\text { „Muzeum to przestrzeń edukacji nieformalnej. Z mojego punktu widzenia } \\
\text { ważne jest wyjaśnienie i odkrywanie, nie zaś nauczanie. Nie chodzi o to, żeby } \\
\text { nauczać, ale o to, żeby się nauczyć. Odbiorca powinien być aktywny i sam } \\
\text { poszukiwać, eksplorować i odkrywać”, Ch5, s. } 4 \text {. } \\
\text { „Cieszy mnie, że większość zwiedzających nie tylko przechodzi przez wy- } \\
\text { stawę, ale też wchodzi z nią w głębszą relację (...).W Polin goście spędzają } \\
\text { około 5-6 godzin, co jest zjawiskiem bez precedensu”, Ch9, s. } 2 \text {. }\end{array}$ \\
\hline Zaskoczony & $\begin{array}{l}\text { „Wychodzili zdziwieni tym, co zobaczyli. To jest bardzo dobre. Kiedy lu- } \\
\text { dzie opuszczają Muzeum Powstania Warszawskiego, nie mają cienia wątpli- } \\
\text { wości - zostali utwierdzeni w przekonaniu, że powstanie słusznym i wielkim } \\
\text { było (...). Ludzie wychodzili z Polin z podważonymi wyobrażeniami. Polacy } \\
\text { wychodzą pod wrażeniem, jak wiele było antysemityzmu, czego rzeczy- } \\
\text { wiście nie są w ogóle świadomi. Zagraniczni Żydzi wychodzą zdumieni, } \\
\text { jak wiele było oprócz antysemityzmu. Jeżeli jakaś instytucja podważa wy- } \\
\text { obrażenia, to znakomicie”, Ch10, s. } 2 \text {. } \\
\text { „Polacy przychodzą odkryć tu muzeum historii Polski i widzą w tym } \\
\text { wartość. Dla Żydów z kolei to miejsce poświęcone ich historii, ale } \\
\text { w dużej mierze tej, o której nie mieli pojęcia. Dla nich zwiedzanie wy- } \\
\text { stawy kończy się olśnieniem. Zdają sobie sprawę z istnienia tej części } \\
\text { żydowskiej przeszłości, która została przyćmiona przez Zagładę”, Ch9, } \\
\text { s. } 2 \text {. }\end{array}$ \\
\hline $\begin{array}{l}\text { „Wezbrana rzeka } \\
\text { zwiedzających” }\end{array}$ & Por. tabela: Jakość, kategoria: liczby, skala zainteresowania. \\
\hline $\begin{array}{l}\text { „Fundament } \\
\text { muzeum” }\end{array}$ & $\begin{array}{l}\text { „Tak naprawdę to nasi widzowie są fundamentem tego muzeum, jego ga- } \\
\text { łęziami, jego podporą - a nie recenzenci czy historycy”, M1, s. } 22 \text {. } \\
\text { „Odbiór zwykłych ludzi jest dla nas najważniejszy, bo jakość wystawy mierzy } \\
\text { się nie tylko przez ludzi zajmujących się ewaluacją wystaw muzealnych, ale } \\
\text { też wrażeniami gości”, Ch9, s. } 2 \text {. }\end{array}$ \\
\hline
\end{tabular}




\begin{tabular}{|l|l|}
\hline Nieco \\
przytłoczony
\end{tabular}$\quad \begin{aligned} & \text { „Jest pewnego rodzaju natłok, bo nie jesteśmy typowym muzeum. Jesteśmy } \\
& \text { połączeniem muzeum i archiwum” (...). „Faktem jest, że jeśli ktoś chce Mu- } \\
& \text { zeum dokładnie zwiedzić, to musi mieć co najmniej } 20 \text { godzin, żeby wszyst- } \\
& \text { ko obejrzeć i przeczytać. To, że nie można tego zrobić za jednym razem, jest } \\
& \text { rzeczywiście w pewnym sensie obezwładniające. Nawet dwie, trzy wizyty to } \\
& \text { za mało. To jest wartość, i pewna słabość. Zostawiamy niedosyt” (....). „Być } \\
& \text { może jeśli się szybko idzie, coś jednak umyka”(...). „Zmęczenie powodu- } \\
& \text { je, że człowiek już przez tę ostatnią galerię przelatuje”, Ch6, s. 3-4. }\end{aligned}$

\section{Próba interpretacji głównych strategii narracyjnych}

Pierwszy wyróżniony przeze mnie element klucza interpretacyjny dotyczy wizji i roli muzeum: wedle jego twórców jest to przede wszystkim świadectwo odrodzenia życia żydowskiego w Polsce, przypominanie o wspólnej historii polsko-żydowskiej. To także wielka opowieść o losach polskich Żydów. Często w poszczególnych wypowiedziach myśli te przeplatają się. W dwóch głosach prasowych mowa była wprost o nowej polskiej narracji historycznej, ukierunkowanej na akcentowanie wielokulturowego dziedzictwa, która otworzyła drogę do stworzenia muzeum. Kolejne trzy wyodrębnione elementy klucza spaja wspólna oś dyskusji - muzeum bardziej polskie czy żydowskie? Przeważają stwierdzenia, że Polin to muzeum polsko-żydowskie ze swej natury, gdyż tak wyglądało życie Żydów na ziemiach polskich. Muzeum to zatem wzajemne splatanie się żydowskości i polskości. Po to, aby ukazać historię Żydów, należy pokazać także szeroki kontekst polski. W niektórych tekstach widoczna jest troska o podkreślenie „żydowskiej duszy” muzeum, starania o pokazanie losów żydowskich „z perspektywy mniejszości”. Jedna krytyczna wypowiedź wobec rezultatów wystawy mówi natomiast wprost, że muzeum prezentuje narrację dominującą (polską), a powinno być bardziej żydowskie. Ciekawe są także próby wyjścia poza utartą dychotomię, wskazujące bądź na międzynarodowych charakter placówki, bądź też możliwość otwartych interpretacji dylematów tożsamości żydowsko-polskiej. W tym kontekście rodzi się pytanie: Kto jest Żydem? (klucz 3). Muzeum musiało zmierzyć się ze ścierającymi się stanowiskami (konwencją, która chce pokazać także ludzi z pochodzeniem żydowskim, nieartykułujących swoich korzeni versus prezentowanie na wystawie wyłącznie osób z żydowską samoidentyfikacją). Wedle jednej ze strategii narracyjnych inicjatorów muzeum nie chce pokazywać osób, które za Żydów się nigdy nie uważały. Analizowane narracje przywołują te dylematy, próbują konfrontować się z naciskami krytyków 
i recenzentów pragnących podkreślić dwukulturowości Żydów obecnych na wystawie oraz ich wkład w rozwój kultury polskiej. W jednym z teksów „Midrasza” czytamy: „Muzeum stara się połączyć dwa stanowiska, ukazując niektóre ważne postaci «pochodzenia żydowskiego», które borykały się z kwestią tożsamości i swojego miejsca w kulturze polskiej" (Rosman, 2014: 63). W moim przekonaniu jest to głębszy problem zewnętrznego przypisywania tożsamości żydowskiej, również nieświadomej czy wręcz filosemickiej chęci podkreślania żydowskich korzeni sławnych Polaków. Kwestie skomplikowanego interpretowania tożsamości Żydów nie są pomijane w prezentowanych narracjach. Z kolei w drukowanym przewodniku po muzeum czytamy: „Nie ma tu bowiem jednoznacznych odpowiedzi na pytania o to, co znaczy być Żydem i czym jest judaizm, gdyż wystawa pokazuje, że Żydem można być na wiele sposobów" (Kirshenblatt-Gimblett, 2015a: 12).

W debaty nad współczesną tożsamością wpisuje się także problem ostatniej wystawy, po 1989 roku (klucz 4). Magazyn „Chidusz” uznał kwestię budowania współczesnej tożsamość żydowskiej za główną oś wywiadów, zaś tę galerię za przejaw „marginalizacji w muzeum Polin życia żydowskiego po 1989 roku” (Bojanowski, 2015: 1). Ta najskromniejsza część muzeum to zatem swoista forma rachunku sumienia dla twórców. Jej „najważniejszą częścią są wywiady z Żydami, którzy w różny sposób mówią o swojej tożsamości. To komfortowa sytuacja, bo oni sami mogą określić, czy chcą o tym mówić otwarcie, czy nie" (Jutkiewicz-Kubiak, 2013: 19). W ostatnim czasie galeria została wzbogacona o kilkuminutowy film, który ma pokazać współczesne życie żydowskie. W tej kwestii przeważają wypowiedzi „obronne” (szczególnie w „Chidusz”), w kategoriach deklaracji na przyszłość, chęci uzupełnienia i poprawienia wystawy. Podobnie, gdy mowa o relacjach z innymi instytucjami, autorzy muzeum zapowiadają, że nie chcą mieć monopolu na „żydowskość” w Polsce. Będą udostępniać pomieszczenia instytucjom żydowskim z dużym upustem, szukają dróg współpracy z Ż̇H, pragną stać się forum dla innych żydowskich organizacji w Polsce.

Tak spektakularne i odważne przedsięwzięcie musi rodzi kontrowersje (klucz 5). Dominują strategie narracyjne akcentujące, iż muzeum stara się pokazać historię stosunków polsko-żydowskich bez wybielania, możliwie obiektywnie, uwzględniając wielość perspektyw i różnorodność dokumentów źródłowych (np. przedwojenny antysemityzm, pogrom kielecki, Marzec '68). Nie pomija się kontrowersji historycznych, nieraz są wręcz uwypuklane poprzez stawianie pytań wewnątrz tekstu. W jednym $\mathrm{z}$ wywiadów autor wylicza główne opozycje binarne, przytacza największe wątpliwości, a także stara się pokonać te dychotomie (Wodziński, 2015). Z kolei, w innej wypowiedzi dowiadujemy się, że fakt, iż spory mogą być ar- 
tykułowane publicznie, to dowód na istnienie nowej Polski i nowego w niej statusu Żydów (Rosman, 2014: 61). W trakcie tworzenia koncepcji poszczególnych galerii, jeśli pojawiły się jakieś naciski, to głównie o charakterze negocjowania pewnych niuansów czy chęci zaakcentowania polskiej racji stanu. W narracjach mowa zarówno o naciskach sponsorów, jak i sił politycznych. Jeden z wywiadów jest w tym względzie zdecydowanie bardziej krytyczny i ujawnia kulisy „negocjowania” historii (Paziński, 2005: 9).

W swych narracjach twórcy muzeum podkreślali wysoką jakość wystawy, jej przełomowość i rozmach inicjatywy (klucz 6). Ten dyskurs wzmacniany jest przede wszystkim liczbami, m.in.: 20-letnim przygotowaniem i badaniami, 1,5 mln odwiedzających, prezentacją 1000 lat historii, licznymi nagrody, a także autorytetami: pracą wybitnych historyków, kwerendami, recenzentami galerii. Nadto, w 2016 roku odbyła się w muzeum konferencja historyczna z udziałem 100 specjalistów w dziedzinie historii Żydów polskich z całego świata, w trakcie której, jak przekonuje nas jeden $\mathrm{z}$ autorów wystawy, „zachęcaliśmy ich do konstruktywnej krytyki, do szukania błędów na wystawie stałej" (Stoła, 2016: 16). W tym kluczu pojawiły się dwie opinie przyznające, że w muzeum jest mało obiektów, lecz tłumaczy się to charakterem muzeum narracyjnego. Tę kwestię wyjaśnia także drukowany przewodnik po wystawie: „Niedostatek dziedzictwa materialnego spróbowaliśmy zrekompensować dziedzictwem niematerialnym: odwołaliśmy się do cytatów wyrażających poglądy ich autorów" (Kirshenblatt-Gimblett, 2015a: 11). Tylko w dwóch wypowiedziach mocno akcentuje się multimedialność placówki, podczas gdy, czytając różne fora internetowe, moją uwagę zwróciło, iż odwiedzający uznają ten element za główny atut muzeum.

Mniej miejsca poświęcono widzowi jako odbiorcy wystawy i jego doznaniom estetycznym. W strategiach narracyjnych widać raczej ukierunkowanie na misję historyczną, oddziaływanie poznawcze i postrzeganie odbiorcy w kategoriach narodowych: Polak, Żyd, Izraelczyk. Publiczność staje się bardziej widoczna przy okazji narracji na temat ogromnego zainteresowania zwiedzających. Ma ona być pozytywnie zaskoczona i pobudzona do refleksji, chętna do ponownej wizyty w Polin. W dwóch wypowiedziach wybrzmiało, że odbiorca to fundament wystawy (jeden wywiad nosi nawet taki tytuł). Z kolei w innym artykule przyznano, że adresat może czuć się przytłoczony ogromem wystawy i jej narracyjnością. Tuż po otwarciu muzeum przed wejściem zbudowano „drzewko marzeń”, na którym każdy mógł zawieszać swoje opinie na temat muzeum. Dzisiaj tę funkcję pełnią ankiety dla zwiedzających. Strategia dominująca to muzeum otwarte na zmianę i gotowe na krytykę, również ze strony turysty. Z pewnością badania sondażowe wśród odwiedzających mogłyby dać pełniejszy obraz dla tej kategorii. 
Analiza wybranych materiałów prasowych dotyczących idei powstania i pierwszych lat funkcjonowania MHŻP pozwala na stwierdzenie, iż strategie dyskursywne nie są jednolite, ale rdzeń przekazu układa się w kilka elementów interpretacyjnych, które odzwierciedlają podstawowe dylematy tożsamościowe (a to z kolei stanowi immanentny element żydowskiej refleksji teoretycznej i społecznej). Z tymi kwestiami musiano także zmierzyć się, tworząc pierwsze żydowskie muzeum w Polsce. W obu czasopismach poświęcono idei stworzenia placówki sporo miejsca. W „Chiduszu” stała się wątkiem przewodnim jednego z numerów w 2015 roku. Poprzez serię wywiadów przybrała formę pytań o budowanie tożsamości żydowskiej w Polsce. Redakcja pisma stoi jednakże na stanowisku, że dyskusja na temat „prezentowania historii Żydów ze zbyt polskiej perspektywy historycznej, wydaje się spóźniona. Ta dyskusja powinna się odbyć w 2006 roku, gdy pierwotna koncepcja wystawy została odrzucona" (Bojanowski, 2015: 1).

Analiza dyskursu powinna opierać się zarówno na tym, „co się (w) nim mówi (tzn. na mechanizmach konstruowania zawartych w nim argumentów, idei czy pojęć), jak i na tym, czego się (w) nim nie mówi (czyli przemilczeniach, brakach i opuszczeniach) (Rapley, 2010: 194). Należy przyznać, że dyskurs twórców muzeum jest otwarty, gotowy do polemik, uwzględniający głosy krytyków. Interesująca jest także siła retoryczna tekstu, w jaki sposób tekst stara się przekonać nas o prawomocności zawartej w nim interpretacji (Rapley, 2010: 197). Przeważają opinie raczej wyważone i stonowane, uwzględniające różne perspektywy, stawiające wewnętrzne pytania - nie zawsze wywołane samym charakterem artykułu (wywiad). Jeden głos jest bardzo krytyczny wobec wypracowanej koncepcji muzeum. Dylematy tożsamościowe są uświadomione, często widać próbę ich przekroczenia, wyjścia poza utarte dychotomie. Narracje starają się uwzględniać konieczność negocjowania znaczeń, kierują naszą uwagę na wielość źródeł historycznych i możliwość wypracowania przez widza własnej opinii, samodzielnego szukania na wystawie wątków bardziej polskich lub bardziej żydowskich. Dyskursy wskazują na konieczne kompromisy podczas budowania koncepcji muzeum. W kilku strategiach ujawniano wewnętrzne spory między twórcami i sponsorami na etapie tworzenia muzeum, a także proces wypracowywania konsensusu. Silniejsza retoryka pojawia się, gdy mowa o rozmachu idei oraz wysiłku dużej grupy kreatorów (muzeum jako „gigantyczne dzieło” i „śmiałe przedsięwzięcie"). Jednocześnie poprzez wskazywanie na zewnętrzne autorytety historyczne oraz podkreślanie wieloletniej pracy grupy historyków akcent pada na szczególną dbałość o rzetelność historyczną. Ta siła retoryczna wypowiedzi ulega nieco złagodzeniu, gdy mowa o tym, że ten odważny i ogromny projekt jest wciąż niezakończony i otwarty na zmiany. 


\section{Literatura}

Blumer H. (2007). Interakcjonizm symboliczny. Kraków.

Bojanowski M. (2015). Co jest najważniejsze w historii Żydów polskich? „Chidusz. Magazyn Żydowski” $\mathrm{nr}$ 14, http://chidusz.com/co-jest-najwazniejsze-w-historii-zydow-polskich/.

Grzymała-Kazłowska A. (2004). Socjologicznie zorientowana analiza dyskursu na tle wspótczesnych badań nad dyskursem. „Kultura i Społeczeństwo” vol. XLVIII, nr 1.

Kirshenblatt-Gimblett B. (2015a). Polin 1000 lat historii Żydów polskich. Przewodnik po wystawie stałej. Warszawa.

Podgórska K. (2014). Muzeum niepodobne do innych. „Nasza Gmina” nr 102.

Rapley T. (2010). Analiza konwersacji, dyskursu i dokumentów. Warszawa.

Szczepanik K. (2012). Zastosowanie analizy treści w badaniach artykułów prasowych - refleksje metodologiczne. „Acta Universitatis Lodziensis. Folia Sociologica” nr 42.

Wodak R., Krzyżanowski M. (2011). Jakościowa analiza dyskursu w naukach społecznych. Warszawa.

\section{Netografia}

http://www.midrasz.pl/miesiecznik/onas, dostęp 20.03.2017.

http://www.cwiszn.pl/pl/pages/show/otwarcie\%20muzeum, dostęp 20.03.2017.

http://www.miasteczkopoznan.pl/node/3, 77dostęp 20.03.2017.

http://www.chidusz.com/, dostęp 20.03.2017.

www.polin.pl/pl, dostęp 20.03.2017.

http://warszawa.jewish.org.pl/images/Biuletyn/zima_2014/kolbojnik_zima_2014_net.pdf, dostęp 20.03.2017.

\section{Teksty źródłowe}

\section{"Midrasz. Pismo Żydowskie"}

Jutkiewicz-Kubiak K. (2013). Fundamentem muzeum sa widzowie, wywiad z Joanną Fikus, koordynatorem projektu wystawy głównej MHŻP i Franciszkiem Zakrzewskim, kuratorem galerii „Powojnie”. „Midrasz. Pismo Żydowskie” nr 3 (173) maj/czerwiec, s. 14-23 (skrót w tabeli: M1).

Paziński P. (2015). Jankiel, chasydzi i Tuwim, rozmowa z Heleną Datner. „Midrasz. Pismo Żydowskie", nr 1 (183) styczeń/luty, s. 5-10 (skrót w tabeli: M3).

Rosman M. (2014). Muzeum Historii Żydów Polskich. Zdecydowanie żydowskie, wyraźnie polskie, „Midrasz. Pismo Żydowskie” nr 2 (178) marzec/kwiecień, s. 58-63 (skrót w tabeli: M2).

\section{"Chidusz. Magazyn Żydowski"}

Andresz K. (2015). Polin - archiwum z precyzyjna struktura, wywiad ze Stanisławem Krajewskim, współtwórcą galerii „Powojnie” w MHŻP. „Chidusz. Magazyn Żydowski” nr 14, http://www. chidusz.com/ (skrót w tabeli: Ch6). 
Bojanowski M. (2015). Jesteśmy tutaj?, wywiad z Marianem Turskim, przewodniczącym Rady MHŻP. „Chidusz. Magazyn Żydowski” nr 14, http://www.chidusz.com/ (skrót w tabeli: Ch7).

Geber K. (2015). Wściekle polskie Polin, „Chidusz. Magazyn Żydowski” nr 20, http://www.chidusz. $\mathrm{com} /$ (skrót w tabeli: Ch10).

Kirshenblatt Gimblet B. (2015b). Rok po otwarciu wystawy stałej w Muzeum Polin, „Chidusz. Magazyn Żydowski" nr 20, http://www.chidusz.com/ (skrót w tabeli: Ch9).

Stoła D. (2016). Dwie nagrody dla Muzeum Historii Żydów Polskich POLIN. „Chidusz. Magazyn Żydowski" nr 30, s. 14-16. (skrót w tabeli: Ch11).

Szajda M. (2014). Jakie kolory ma historia, wywiad z Marcinem Wodzińskim, twórcą galerii XIX wieku w MHŻP, „Chidusz. Magazyn Żydowski” nr 12, http://www.chidusz.com (skrót w tabeli: Ch4).

Wodziński M. (2015). Muzeum Historii Żydów Polskich czy Muzeum Historii Polski?, „Chidusz. Magazyn Żydowski" nr 15, http://www.chidusz.com/ (skrót w tabeli: Ch8).

Wójcik M., Bojanowski M. (2015). Na ile żydowskie jest żydowskie muzeum?, wywiad z Barbarą Kirshenblatt-Gimblett, główną kuratorką wystawy stałej MHŻP. „Chidusz. Magazyn Żydowski” nr 14, http://www.chidusz.com (skrót w tabeli: Ch5). 